\title{
Review
}

\section{Law and the philosophy of privacy}

Janice Richardson

Routledge, London, 2016, 226pp., ISBN: 978-0415572439

Contemporary Political Theory (2017) 16, 402-404. doi:10.1057/s41296-016-0019-5; advance online publication 23 August 2016

This is a frustrating book: on the one hand, it promises a new outlook on the philosophy of privacy, based upon the work of Luciano Floridi and Baruch Spinoza, which is a welcome extension of the sources used to think about privacy in contemporary political philosophy; on the other hand, it virtually ignores the existing literature on the philosophy and law of privacy. As the presentation of the legal and philosophical issues tends to be schematic, it is quite difficult to know what the book offers by way of additions and corrections to the larger literature on privacy. The book has a bibliography after each chapter, which makes it hard to assess the sources overall, and to find references, unless you remember the chapter in which they occurred. This reinforces the sense that what is presented as a monograph is really a set of independent essays or lectures which, while individually interesting, do not give the reader a clearer sense of the way legal and philosophical issues about privacy fit together.

For example, while the book discusses some cases from legal history and makes reference to particular contemporary bodies of law, there are no systematic discussion of the premises about the relationship of philosophy and law relevant to the analysis of privacy; no discussion of whether or why different forms of law might matter to privacy (differences between private law and public law, say, or between tort law and constitutional law); and no discussion of what makes something law and, therefore, how we are meant to recognise law when we see it (Does it have to be applied? Are all judicial interpretations equally lawful?). So if the reader is hoping for a systematic examination of the relationship between law and the philosophy of privacy, she is likely to be disappointed. On the other hand, she may enjoy a brief guide to the ideas of Spinoza and Floridi, and an enjoyable critique of Posner's effort to treat privacy as simply one commodity amongst others.

A theme running through the book is the significance of privacy for the way we see ourselves, although we are offered no systematic discussion of the way that privacy (or different ways of conceptualising it) affects people's self-conceptions, or of how the legal treatment of privacy does so. We can therefore agree with - and

(C) 2016 Macmillan Publishers Ltd. 1470-8914 Contemporary Political Theory Vol. 16, 3, 402-404 www.palgrave.com/journals 
enjoy - Richardson's response to Gary Becker's claim that black youngsters from deprived backgrounds should be told how important it is to remain in college, and treated to statistics on the likelihood that their marriages will fail, that they will be unemployed and that they will die early if they drop out, in order to motivate them: 'I doubt that this information would come as news to them. He occludes the pressures upon them to leave and as such omits the statistics relating to their chances of staying in college. They do not need Becker playing the role of a life coach - or an image of themselves as human capital - but solutions that acknowledge the economic and social reasons for their position' (p. 132). But on the question of whether it is wrong to commodify all types of personal information, of whether and/or how commodifying information about us leads us to think of ourselves as commodities, of what will count as commodifying personal information (Is the standard the same for all types of personal information? For all information?), of whether commodification should be prevented by law (at least in the case of privacy), we are left little the wiser. (People interested in pursuing these questions may be helped by a recent article by Beate Roessler on the topic, as well as by other contributions to The Social Dimensions of Privacy, which she has edited with Dorota Mokrosinka (see Roessler and Mokrosinka, 2015).

Likewise, while Richardson reiterates the well-worn evidence that in the nineteenth century the public/private split was based in part upon the paradigm of the (bourgeois) home as the private sphere, we get no discussion of what it would be like to think of the public/private distinction some other way, or of what aspects, if any, of home life ought to be seen as private. The implications for the twenty-first century of the critique of nineteenth century views of privacy are, therefore, uncertain.

It is not that the book is not a mine of interesting information and insights. There is much that is interesting and helpful. But it is frustrating to have a discussion of Vogel's and Pateman's views of the marriage contract which ends with the helpful idea that 'Both marriage and employment should be considered together because marriage represents an important part of the story of subordination...' (p. 50) with no follow-up on what that might mean (What aspects of marriage and employment need to be seen together? What would that mean for discussions of overtime rights and duties, of zero-hours contracts, of unemployment benefits?). And it is particularly frustrating that Richardson never discusses Pateman's (1988) work on the gendered nature of citizenship and welfare, or considers what relevance it might have now, when the welfare state in countries like Britain and the USA is but a shadow of its former self, and when improvements (albeit uneven) on feminist issues like marital rape and domestic violence, or the recognition of women's capacities for leadership, coexist with a near stalemate on issues of equal pay, on the treatment of poverty as a feminist issue, or on the ability to bring academic insights on intersectionality into the treatment of social policy.

(C) 2016 Macmillan Publishers Ltd. 1470-8914 Contemporary Political Theory Vol. 16, 3, 402-404 
Finally, the critique of liberal and neo-liberal ideas of privacy, which takes up a great deal of this book, will be familiar already to anyone who is acquainted with the feminist-inspired philosophical and legal literature on privacy since the late 1980s - with the writings, for example, of Anita Allen, Patricia Boling, Jean Cohen, Judith deCew, Beate Roessler, Frances Olson, Sylvia Law, or with the work of Catherine MacKinnon, Susan Okin, Iris Marion Young and Drucilla Cornell. Granted, there is something refreshing about a book on privacy that takes feminist critiques of privacy seriously but does not feel obliged to address MacKinnon's views on privacy (though Richardson does discuss Thomson's 1975 non-feminist claim that a right to privacy is just a right to property ownership in disguise - an article which has motivated more discussions of the best way to define a right to privacy even than the famous reference to 'a right to be let alone' in Warren and Brandeis' 1984 [1890] Harvard Law Review article, which explained why privacy rights should not be confused with property rights).

But it is one thing to acknowledge a large and extensive literature that one does not intend to use, and quite another to act as though it does not exist. This is, therefore, a frustrating book to read, as it seems neither to meet the needs of those approaching the topic of privacy for the first time, nor to provide the depth, consistency and sophistication that with some acquaintance with the legal and philosophical dimensions of privacy are likely to need.

\section{References}

Pateman, C. (1988) The patriarchal welfare state. In A. Gutmann (ed.) Democracy and the Welfare State. Princeton, NJ: Princeton University Press.

Roessler, B. and Mokrosinka, D. (2015) Social Dimensions of Privacy: Interdisciplinary Perspectives. Cambridge: Cambridge University Press.

Thomson, J.J. (1975) The right to privacy. Philosophy and Public Affairs 4(4): 295-314.

Warren, S.D. and Brandeis, L.D. (1984 [1890]). The right to privacy [the implicit made explicit]. In F.D. Schoeman (ed.) Philosophical Dimensions of Privacy: An Anthology. Cambridge: Cambridge University Press.

Annabelle Lever

University of Geneva, 1211 Geneva 4, Switzerland annabelle.lever@unige.ch 